\title{
Arts and Politics
}

\author{
Vera L. Zolberg
}

Published online: 2 July 2010

(C) Springer Science+Business Media, LLC 2010

The international conference on Arts and Politics: Franco-American Perspectives organized at the University of Paris X-Nanterre under the aegis of the Institute for Social Sciences of Politics in November 2007 served as an important opportunity to bring together a number of scholars from both countries for fruitful inquiry. On that occasion, we were able to explore the frequently vexed intersections of culture and politics to whose study this journal has devoted itself for many decades. This special issue of the Journal of Politics, Culture, and Society is based on the revised translation of a selection of the papers dealing with the arts that have been published in French (Roussel 2010, with the publisher's kind permission).

To some degree, comparing France and the USA must begin from their unique heritage as two important democratic republics. Yet they differ sharply with regard to political traditions, structures of governance at the national and local levels, and population composition. This is especially true of the state traditions of these countries. A strong state has been an outstanding attribute of France for centuries, almost regardless of regime, in sharp contrast to the USA, where the importance of Washington, DC, is of relatively recent vintage. Centralization in Paris of culture and cultural policy, as with most other domains, has no counterpart in the USA, where not only does decentralization of political authority predominate, but the private sector is permitted - in fact invited to play an important role in cultural activity. These principles underlie the analysis presented by Violaine Roussel in her engaging and informative general introduction to the papers she edited.

On a more personal note, I wish to thank Professor Roussel and her associates for their imaginative conceptualization of the themes developed by the scholars whom she invited to participate in the conference. At its best, sociology is an ongoing conversation in which ideas are exchanged that may lead to unexpected developments in knowledge. This is what occurred to me a year after rereading a statement by Elizabeth Long (2007) on "Stories as Models," in which she proposed ways in which anecdotes and small stories that sociologists use, often to introduce their work or exemplify a point. These, she argues, are actually "carriers of theory that do important cognitive work to create or revise conceptual 
categories and innovate in theoretical models or frames." I wish to pursue her suggestions in my field of interest, the sociology of collective memory. It is a domain that has become popular largely, I believe, because it provides opportunities for us to delve deeply into history, identity, and many other domains of social constructivism. In reading Elizabeth Long, I realized that the kinds of personal experiences that she calls upon are often hidden away by scholars as lacking in scientific legitimacy, and I confess that I had a similar reaction upon first reading Maurice Halbwachs' $(1980,1992)$ seminal works, in which he evokes as data his own memories and even literary works. ${ }^{1}$ Whereas anthropologists and poststructural analysts more generally have opened up these black boxes (Geertz 1995), I am now trying to overcome my earlier prejudices and will use a personal "story" to bolster this guidance.

The international conference, as noted above, was scheduled to take place at the University of Paris - Nanterre, to which all participants were to make their way 1 day in November, 2007, mostly by way of the suburban railroad out of Paris (the RER). There was some concern about arriving on time because a student strike had been announced that might have some consequences for the meeting - delay in starting the sessions, disruption of the proceedings, meal service in the faculty restaurant, barriers to keep out participants, etc. As it happens, none of our fears came to pass, and except that few students attended the sessions, the meetings went off without major problems. Still, for one who had lived in Paris during the tumultuous spring of 1968, the relative tranquility of the Nanterre campus came as a surprise.

It should be remembered that the French university was (and largely still is) a unitary, centralized institution, despite the creation of divisions such as Nanterre (and by now many more). For those of us who were living in France during the year that seemed destined to mark the world as no other had done, it is hard to believe that four decades have passed since so much turmoil, promise, and disenchantment could have been jammed into so brief a moment. Its impact has seemingly been overshadowed by even more recent events, which will, no doubt, produce some of their own elations or disillusionments, but the "alumni" of that moment in Paris, as the late film maker, Jean Rouch, who was there as well, put it, were permanently marked and would persist in viewing it as a formative utopian instant for themselves and for their world. Judging from the numerous attempts to assess the impact of the month, year, season - the time frame varies, depending upon how those events played out in different places around the globe-Rouch was correct in this early intuition that it has served as a badge of kinship akin to that of a "graduating class," members of which sense a fictive community even if their experience took place in very different sites and nations, under divergent levels of seriousness, ranging from mere discomfort to terrible risk.

These observations were brought to my attention when in 2008 I was invited to participate in an exercise in "collective memory" that took place at my university, under the title "Moments of Madness." 2 Other participants included members of the "1968 graduating class" with experiences in Eastern Europe (Poland, Czechoslovakia), Paris, as well as faculty or students from a number of American universities. Whereas the audience of "alumni" like ourselves, 40 years older, were eager to share their own experiences, the

\footnotetext{
${ }^{1}$ As a field of study, it reached American sociology somewhat belatedly, with the posthumous translation of Halbwach's works. Whereas the collected essays published by the University of Chicago Press (1992) remain in print, his major study (1980), published by a commercial press, was allowed to die.

2 The article "Moments of madness" by Aristide R. Zolberg was originally published in 1972. It has been reprinted in Zolberg (2008). Its title inspired Elzbieta Matynia, of the Sociology Department of the New School for Social Research, to adopt it as the theme for a multinational consideration of that anno mirabilis.
} 
majority were students, for whom the recollections were part of the lore, sometimes nostalgia, and occasional attempts at scholarly analysis as we struggled to grasp threads of the temps perdu.

For Americans like myself, to be within walking distance of the Sorbonne, the Théatre de l'Odéon, or the barricades of the Boulevard St. Michel, it seemed as if a new revolution might be in the works. On the other hand, having been invited to dinner by French friends, who insisted that their sons, university students, join us, we could not help feeling a certain degree of skepticism. How could we not, given that the meal was exquisite, the young men fashionably dressed in handsome tweed suit jackets with suede elbow patches and flannel trousers (that era's "preppy" style), and upon leaving after having their dessert and espresso, promised their parents to be home before the CRS (national police) started to throw tear gas canisters in their vicinity.

Our impression was further supported when, on another evening, at the Grand Amphithéâtre of the Sorbonne, we discovered that it was not only our friends' sons who dressed fashionably, but nearly everyone else, in what seemed to be the university students' uniform. In this immensely crowded setting, the degree of politesse was astonishing. It seemed as if every second phrase uttered was on the order of "Pardon monsieur; pardon madame." It was different for the presiders on stage, however, almost as if Goffman's front stage and back stage were reversed. The public face presented by the organizers was exemplified as they entertained motions to paint over the overbearing, allegorical mural of Puvis de Chavanne (a motion that I and some others would gladly have seconded), but it was voted down (if anyone was counting; Goffman 1963).

More impressively, however, was the introduction by the chair of a man from the audience who looked different from the university students. This, announced the chair, "is a worker" [un ouvrier], wearing a bulky brown leather jacket (clearly no elegant, black, Italian name brand) over his muscular frame. The audience seemed stunned into momentary silence, then burst into enthusiastic applause. Had they never seen a worker before? Bourdieu's (1984 [1979]) analysis of habitus would have been appropriate in that instance. These observations, I realized, helped me make sense of the more conventional analysis of the structure of the French state, the educational institution, and the system of inequality as adumbrated by Bourdieu (1964) and many others.

Yet, while I was in Paris, the other participants at our symposium had experienced a very different 1968. For us, there was the disquieting news from the USA where Martin Luther King, Jr., was assassinated, followed not long after by Robert F. Kennedy; news filtering in from the Mexican government's assault and murder of student demonstrators; and much other protest and repression around the world, especially the Prague Spring and hopes for a humanistic communism, shattered by the invasion of Soviet tanks in August. By comparison, I began to think of the Parisian events as relatively minor - at best, problems of "the society of managed consumerism"- as Jean-Luc Godard showed in his films of that era, such as Weekend. But there was much more to it than could be expressed in something other than superficial consumerism, and this may indicate the limitations of "sidewalk sociology" or decontextualized anecdotal experiences.

What happened in France in 1968 had been brewing for more than a little time, with roots in the nineteenth century and much earlier if we think of the deeply centralized structure of the French state. Not surprisingly, the most immediate conditions may be found in the structures of the institutions central to French political, economic, demographic, cultural, and social organization. For Paris in 1968, what came to be known as the events of May began on the troubled campus at a suburb of Paris called Nanterre, spread to the Latin Quarter of Paris and from there gained much of France, flowing from the educational 
sphere into the realms of discontent in economic and political activity. During this period, following the lead of university students, almost every organized group in France voiced its demands simultaneously; potential groupings suddenly became organized, adding their clamor to the general din; authority vacillated; the impact of demonstrations mounted; and finally while some groups retreated from the fray altogether, others settled down at the bargaining table to await their turn to negotiate. Given the centrality of the educational institution to the emergence of the particular moments of madness in 1968, it seems logical to see what its features were in France-how did it resemble those of other nations and what was particular to France. Serious trouble developed from 1963 on when the Gaullist government boldly decided to revamp what they saw as an outdated educational system. It had remained essentially unchanged since its design in the nineteenth century, during the early years of the Third Republic, to suit that regime's specific civilian and military manpower needs and to provide appropriate patterns of political socialization. In an even longer French tradition that continues despite decades of political rhetoric to the contrary, education was centralized in policy and its bureaucratic implementation. Only now, it was intended to foster commitment to republicanism by institutionalizing meritocratic access to upper and middle positions, as well as bolster secularism in the dominant culture.

But immediately after World War II, democratic critics started to question the authoritarianism of its methods and the advantages it gave, tacitly, to the bourgeoisie. While some reforms in elementary schools had been instituted earlier, by the Popular Front government, the post-primary level remained fairly untouched. Despite a variety of different kinds of secondary schools, only one kind, the lycée, could lead to the university. But gaining access to the lycée was not automatic. Admission was determined early: as in England's 11+ plus examinations, in France at about the same age, all school children had to pass the entrée en sixième examination. Generally, by age 11, one's educational future was determined - if one failed, it might be repeated; if one passed, one would be "oriented" to either a form of terminal high school or, if at a high enough level and with the right courses as background, the university-bound lycée. The idea had been meritocratic, but it turned out to be a barrier to entry into academic secondary school education. Another barrier existed by the requirement of having to have studied Latin from early post-primary entry point, but only the lycée provided classical languages. Truly, this was not a system for "late bloomers," and the filtering process continued at later levels as well (Willis 1972).

Only shortly before the second world war and immediately after the Liberation were serious proposals for reform of the system introduced. In particular, democratic reformers tried to eliminate the highly esteemed Latin as the sine qua non for admission to the lycée and subsequently to the university. Those parents who could afford it provided their children with Latin as early as age 8 , mostly by private tutoring or by enrollment in feepaying classes, rather than send their children to free municipal elementary schools that did not offer it. Faculty members who opposed modernization used their influence to maintain separate schools and/or separate tracks within the new post-World War II common high schools. But even the small changes that were instituted continued to reproduce similar results: students of higher-status parents were far more likely to be "advised" (oriented) into academic tracks and lower-status students into terminal post-primary schooling.

On top of these structural impediments, post-World War II France's demography was changing in unforeseen ways. As the first western country to have reached "zero-population growth" in the nineteenth century, for the first time in nearly a century, the birthrate rose dramatically, leading to overcrowding at every educational level in succession. Even postWorld War II's highly selective educational system could not stem the numbers. At the university, students became an anonymous mass to remote professors. Yet the total student 
body in the mid-1960s represented only $5 \%$ of the university age cohort; and of those in the university, fewer than $10 \%$ were worker's children. Through a system of yearly examinations, most of them failed to pass exams for the more desirable faculties, such as medicine or law, or were "oriented" into preparation for dead-end employment— - "the Faculty of Letters" which housed the least prestigious field-sociology (Zolberg and Zolberg 1969). Meanwhile, concerned about criticism of France's economic and technical backwardness compared to other nations, DeGaulle's Fifth Republic constructed more school buildings, hired more staff, and diverted students into other tracks than academic. But these responses contributed to the creation of new critical situations which provided a direct link to the events of May.

Nanterre was one of these reform ideas gone wrong. Although it was supposed to be a campus similar to those in the USA and, instead of the huge amphitheaters of the Sorbonne, moderate-size class rooms were built, yet library and recreational facilities were put on hold. Nanterre, at the time a virtual shantytown on the outskirts of Paris, immediately became overcrowded, drawing many of its students not from Nanterre's working-class residents but from Paris itself; most of its faculty members commuted from Paris, generally did not bring their families, and spent as little time there as possible. ${ }^{3}$ Faculty recruitment remained largely traditional, so that there was a chronic shortage of qualified instructors, leaving most of the teaching in the hands of low-level adjuncts - "assistants."

Unlike American teaching assistants, for whom this was a temporary position, in France, it was a marginalized occupation that could last for a very long time, depending upon budgetary funding provided for new positions. Poor working conditions led to union organizing; some joined in protest against the Algerian War, but most also demanded improvements in the status of these marginalized assistants. Starting with bread and butter issues, eventually their associations became a vanguard of the wave of opposition to the Fifth Republic's university reform; its authoritarian impositions with no consultation of those affected - faculty, students, their families - led their syndicats (unions) to denounce the technocratic orientation of the proposals, many inspired by American university developments - the "multiversity" attempt at Berkeley, for example — as an adaptation of the university to the needs of capitalist society. This theme, elaborated simultaneously by the educational specialists of the French Communist Party provided a framework that transformed debate over the reforms into a genuine ideological struggle over the future of French society.

It would be a mistake to think that all the assistants and students were united - in fact they became fragmented over the next couple of years - including CPF members who split into orthodox elements challenged by "Italians," "Cubans," "Maoists," and Socialists, who split into Trotskyite and Anarchist groups. Any or all of them came to denounce American policies in Vietnam, including by launching some attacks on American establishments off campus. They seemed on the verge of clashing with the Occident group a pro-colonialist faction which had its origins in the Algerian War and had since come to defend "traditional French institutions" and to favor American foreign policy in Vietnam. It was probably the clashes between these groups that led the rector of the Sorbonne to call in the Paris police on May 3, 1968, a decision that can be viewed as the dramatic, but not unlikely climax

\footnotetext{
${ }^{3}$ The Nanterre that exists today no longer resembles a bidonville [shantytown]. The campus buildings are not unattractive, though simply constructed; luncheon served the participants by professional waiters was tasty; students on the grounds represented ethnic and racial variety and wore current fashion; the head of campus security, a black Frenchman, in a handsome, official-looking blazer, was proud of the good order he and his aides had maintained but did not discuss the student action.
} 
of processes generated by existing institutional structures within the French educational system.

In the aftermath of the 1968 events, numerous commissions were set up to diagnose the problematic nature of French institutions. The first and most striking of the findings was to try to alleviate the extreme selectivity of access to higher education brought about in part by institutional structures. The immediate solution offered made headlines in virtually every newspaper in France: NO LATIN BEFORE THE 3rd YEAR OF SECONDARY SCHOOL.

This analysis does not account for such an extraordinary period in the world, or even in France, but it suggests that a multiplicity of institutional, demographic, political, historical, and cultural patterns needs to be marshaled in order to pinpoint the structures and processes that help produce certain events. It is important as well to bring to bear the increasing importance of technology of communication, the importance of media in conveying the responses of people to the particular set of patterns and structures they face. In addition to such study, the researcher's on-site observation and openness to the anecdotal can help us to understand the events that otherwise may have seemed either obvious or mysterious to those who lived through them. To some degree, it helps to anchor many of the studies that make up the contributions by the authors of this issue whose case studies follow.

\section{References}

Bourdieu, P. (1964). Les héritiers: Les étudiants et la culture. Paris: Les Éditions de Minuit (University of Chicago Press, 1979).

Bourdieu, P. (1984). Distinction: A social critique of the judgement of taste. Cambridge: Harvard University Press. Original version published 1979.

Geertz, C. (1995). After the fact: Two countries, four decades, one anthropologist. Cambridge: Harvard University Press.

Goffman, E. (1963). Behavior in public places: Notes on the social organization of gatherings. New York: Free Press.

Halbwachs, M. (1980). The collective memory. New York: Harper \& Row.

Halbwachs, M. (1992). On collective memory (L. Coser, Trans.). Chicago: University of Chicago Press.

Long, E. (2007). Letter to Lynn Spillman for transmission to the Culture Section, from Elizabeth Long, Rice University, at elong@rice.edu

Roussel, V. (Ed.). (2010). Les artistes et la politique. Terrains franco-américains. Saint-Denis: Presses Universitaires de Vincennes.

Willis, P. (1972). Learning to labour: How working class kids get working class jobs. New York: Columbia University Press.

Zolberg, A. R. (1972). Moments of madness. Politics and Society, 2(2), 183-207 (Winter 1972).

Zolberg, A. R. (2008). How many exceptionalisms?: Explorations in comparative macroanalysis. Philadelphia: Temple University Press. in a series edited by John Torpey.

Zolberg, A. R., \& Zolberg, V. L. (1969). The meanings of May (Paris, 1968). Midway, 91-109 (Winter 1969). 